\title{
TUMBUH KEMBANG BAYI YANG MENDAPATKAN ASI EKSKLUSIF DIWILAYAH KERJA PUSKESMAS SIMPANG BARU KOTA PEKANBARU
}

\author{
THE GROWTH AND DEVELOPMENT OF EXCLUSIVE BREASTFEED BABIES \\ AT THE PUSKESMAS SIMPANG BARU PEKANBARU
}

\author{
Sara Herlina \\ Program Studi D-III Kebidanan, Fakultas Kedokteran dan Ilmu Kesehatan, \\ Universitas Abdurrab Pekanbaru \\ Email: sara.herlina@univrab.ac.id
}

\begin{abstract}
ABSTRAK
Tumbuh kembang anak sangat erat kaitannya dengan status gizi pada anak.Di Indonesia angka kekurangan gizi mengalami peningkatan dari tahun 2010 ke tahun 2013. Pada tahun 2013 terdapat 19,6 persen balita kekurangan gizi yang terdiri dari 13,9 persen gizi kurang dan 5,7 persen gizi buruk, sedangkan tahun 2010 terdapat 17,9 persen balita kekurangan gizi terdiri dari 13,0 persen gizi kurang, 4,9 persen gizi buruk (Riskesdas, 2013). Peneliti juga melakukan survei pendahuluan dengan melakukan pemeriksaan tumbuh kembangan terhadap 50 orang bayi yang berusia 6-12 bulan di Wilayah Kerja Puskesmas Simpang Baru, dari 50 bayi terdapat 30 bayi (60,0 persen) yang tidak ASI eksklusif mengalami dua gangguan tumbuh kembang sebanyak 11 bayi (36,6 persen) dan 20 bayi (40,0 persen) yang ASI eksklusif mengalami dua gangguan tumbuh kembang hanya 3 bayi (15 persen). Penelitian ini bertujuan untuk mengetahui tumbuh kembang bayi yang mendapatkan ASI eksklusif. Desain penelitian ini adalah cross sectional dengan besar sampel 151 orang.Metode sampling yang digunakan systematis random sampling.Analisis data dilakukan secara univariat, bivariat dan multivariat. Hasil penelitian diperoleh gangguan tumbuh kembang sebanyak 41 orang (27\%). Hasil analisis multivariat variabel yang berhubungan dengan tumbuh kembang bayi adalah variabel ASI esklusif (gangguan pertumbuhan POR: 3,1 CI95\% 0,99,8, gangguan perkembangan POR: 1,8 CI95\% 0,6-5,2, gangguan tumbuh kembang POR: 3,6 CI95\% 1,2-10,6), pekerjaan ibu (gangguan pertumbuhan POR: 1,4CI95\% 0,4-4,9, gangguan perkembangan POR: 1,5CI95\% 0,5-4,8, gangguan tumbuh kembang POR: 5,4 CI95\% 1,83615,914), pengetahuan ibu (gangguan pertumbuhan POR: 3,3CI95\% 1,1-9,9, gangguan perkembangan 1,5 CI95\% 0,5-4,3 , gangguan tumbuh kembang POR: 4,5 CI95\% 1,6-12,8), lingkungan pengasuhan (gangguan pertumbuhan POR: 1,3C195\% 0,6-4,9, gangguan perkembangan POR: 2,5C195\% 1,3-5,0, gangguan tumbuh kembangPOR: 2,9 CI95\% 1,4-5,9), konsumsi makanan (gangguan pertumbuhan POR: 3,4C195\% 1,1-10,1, gangguan perkembangan POR 2,0CI95\% 0,7-5,4, gangguan tumbuh kembang POR: 1,3 CI95\% 0,4-3,7). ASI eksklusif merupakan faktor utama pada tumbuh kembang bayi dan ada faktor lain yang berhubungan yaitu pengetahuan ibu, pekerjaan ibu, konsumsi makanan dan lingkungan pengasuhan.
\end{abstract}

Kata Kunci : ASI eksklusif, Bayi, Tumbuh kembang

\begin{abstract}
Child development is closely related to nutritional status in children. In Indonesia malnutrition rates have increased from 2010 to 2013. In 2013 there were 19.6 percent of malnourished children who were malnourished consisting of 13.9 percent of undernourished and 5.7 percent of malnutrition, while in 2010 there were 17.9 percent of malnourished children consisting of 13.0 percent of malnutrition, 4.9 percent of malnutrition (Riskesdas, 2013). Researchers also conducted a preliminary survey by examining growth and development of 50 babies aged 6-12 months in the Simpang Baru Health Center Work Area, of 50 babies there were 30 babies (60.0 percent) who were not exclusively breastfed having two growth disorders as many as 11 babies (36.6 percent) and 20 babies (40.0 percent) who exclusively breastfed experienced two growth disorders and only 3 babies (15 percent). This research aims was to understand growth and development baby getting
\end{abstract}


exclusive breastfeeding. Analytic cross sectional research was conducted with a sample size of 151. The samplewas collected using systematis random sampling. Data analysis was performed using univariat, bivariat and multivariate. The result that two disruption growth and development as much as 41 people (27\%). The logistic multivariateanalysis show that variable associated growth and development baby wasexclusive breastfeeding (impaired growth POR: 3,1 CI95\% 0,99,8, development disordes POR: 1,8 CI95\% 0,6-5,2, growth disordes POR: 3,6 CI95\% 1,2-10,6), mother's occupation (impaired growth POR: 1,4CI95\% 0,4-4,9, development disordes POR: 1,5 CI95\% 0,5-4,8, growth disordes POR: 5,4 CI95\% 1,836-15,914), mother's knowledge (impaired growth POR: 3,3CI95\% 1,1-9,9, development disordes 1,5 CI95\% 0,5-4,3, growth disordes POR: 4,5 CI95\% 1,6-12,8), nurturing environment (impaired growth POR: 1,3CI95\% 0,6-4,9, development disordes POR: 2,5 CI95\% 1,3-5,0, growth disordes POR: 2,9 CI95\% 1,4-5,9), food consumption(impaired growth POR: 3,4CI95\% 1,1-10,1, development disordes POR 2,0 CI95\% 0,7-5,4, growth disordes POR: 1,3 CI95\% 0,4-3,7). Exclusive breastfeeding is a major factor in the growth and development of infants and other factors are related, mother's knowledge, mother's occupation, ,nurturing environment, food consumption, Growth and development

Key words: Exclusive breastfeeding, Baby, Growth and development

\section{PENDAHULUAN}

Tumbuh dapat juga diartikan sebagai bertambahnya ukuran dan jumlah sel di seluruh bagian tubuh yang secara kuantitatif dapat diukur, seperti tinggi badan, berat badan, dan lingkar kepala. Kembang adalah bertambah sempurnanya fungsi alat tubuh yang dapat dicapai melalui belajar, terdiri dari kemampuan gerak kasar dan halus, pendengaran, penglihatan, komunikasi, bicara, emosi-sosial,kemandirian, intelegensia, dan perkembangan moral (Muslihatun, 2011). Dengan demikian tumbuh kembang adalah proses yang berkesinambungan dan sulit untuk dipisahkan antara perubahan fisik seperti bertambahnya ukuran berat badan, panjang badan dan perubahan kemampuan bayi seperti kemampuan gerak kasar, halus, bicara, dan emosi sosial (Soetjiningsih, 2014).

Tumbuh kembang anak sangat erat kaitannya dengan status gizi pada anak.Di Indonesia angka kekurangan gizi mengalami peningkatan dari tahun 2010 ke tahun 2013. Pada tahun 2013 terdapat 19,6 persen balita kekurangan gizi yang terdiri dari 13,9 persen gizi kurang dan 5,7 persen gizi buruk, sedangkan tahun 2010 terdapat 17,9 persen balita kekurangan gizi terdiri dari 13,0 persen gizi kurang, 4,9 persen gizi buruk (Riskesdas, 2013). Balita dengan status gizi kurang di Riau tahun 2013 meningkat dibandingkan tahun 2012 yaitu dari 9,4 persen menjadi 10,57 persen. Prevalensi gizi buruk juga mengalami peningkatan, yaitu 0,74 persen pada tahun 2012 dan meningkat menjadi 1,57 persen pada tahun 2013 (Dinkes Riau, 2013)

Dampak buruk yang dapat ditimbulkan oleh masalah gizi pada 1000 hari pertama kehidupan adalah terganggunya perkembangan otak, kecerdasan, gangguan pertumbuhan fisik, dan gangguan metabolisme dalam tubuh. Menurunnya kemampuan kognitif dan prestasi belajar, menurunnya kekebalan tubuh sehingga mudah sakit, dan resiko tinggi untuk munculnya penyakit diabetes, kegemukan, penyakit jantung dan pembuluh darah, kanker, stroke, dan disabilitas pada usia tua. Kesemuanya itu akan menurunkan kualitas sumber daya manusia Indonesia, produktifitas, dan daya saing bangsa (Achadi, 2014).

Pertumbuhan dan perkembangan anak dipengaruhi oleh pemberian ASI eksklusif pada umur $0-6$ bulan 
pertama kelahiran karena ASI merupakan zat gizi yang paling sempurna untuk bayi karena mengandung antibodi sehingga anak jarang sakit sehingga tidak mengalami penurunan berat badan dan dengan menyusui terjadinya ikatan kasih sayang antara ibu dan bayi sehingga mempengaruhi perkembangan janin (Yuniarti, 2015).

Hasil penelitian yang dilakukan oleh Andria, et al (2013) menunjukkan bahwa hasil pengukuran perkembangan $p$ value $=0,048$, dan hasil pengukuran pertumbuhan $p$ value $=0,043$. Sehingga dapat disimpulkan bahwa 1762 orang, terdapat berat badan bayi yang dibawah garis merah sebanyak 5 orang $(0,28$ persen $)$ dan terdapat keterlambatan perkembangan sebanyak 38 orang (2,16 persen). Peneliti juga melakukan survei pendahuluan dengan melakukan pemeriksaan tumbuh kembangan terhadap 50 orang bayi yang berusia 6-12 bulan di Wilayah Kerja Puskesmas Simpang Baru, dari 50 bayi terdapat 30 bayi (60,0 persen) yang tidak ASI eksklusif mengalami dua gangguan tumbuh kembang sebanyak 11 bayi (36,6 persen) dan 20 bayi (40,0 persen) yang ASI eksklusif mengalami dua gangguan tumbuh kembang hanya 3 bayi (15 persen). Di Puskesmas Simpang Baru juga belum pernah dilakukan penelitian tentang tumbuh kembang pada bayi yang mendapatkan ASI eksklusif, oleh karena itu peneliti tertarik melakukan penelitian tentang tumbuh kembang bayi yang mendapatkan ASI eksklusif di Wilayah Kerja Puskesmas Simpang Baru Kota Pekanbaru tahun 2016. Penelitian ini bertujuan untuk mengetahui tumbuh kembang bayi yang mendapatkan ASI eksklusif di Wilayah Kerja Puskesmas Simpang terdapat perbedaan antara pemberian ASI eksklusif dan susu formula terhadap tumbuh kembang bayi usia 612 bulan di desa Sungai Sirih Kecamatan Singingi Kabupaten Kuantan Singingi dan Hasil penelitian Sarlis (2015) di Wilayah Kerja Puskesmas Garuda menunjukkan bayi usia enam bulan yang mengalami keterlambatan perkembangan sebanyak 21 persen.

Data dari Dinas Kesehatan Kota Pekanbaru tahun 2014 menunjukkan bahwa dari 20 Puskesmas yang ada di Kota Pekanbaru jumlah bayi di Puskesmas Simpang Baru sebanyak Baru Kota Pekanbaru Tahun 2016. Diharapkan ibu-ibu yang mempunyai bayi mengerti akan pentingnya ASI eksklusif bagi bayi untuk tumbuh kembang bayi, dan diharapkan kepada tenaga kesehatan untuk menghimbau masyarakat untuk memberikan ASI eksklusif agar tidak terdapat gangguan tumbuh kembang bayi.

\section{METODE PENELITIAN}

Jenis penelitian adalah kuntitatif analitik dengan desain yang digunakan adalah Cross-sectional Study. Penelitian ini dilakukan diwilayah kerja Puskesmas Simpang Baru Kota Pekanbaru dari bulan FebruariAgustus 2016. Populasi dalam penelitian ini adalah seluruh ibu yang mempunyai bayi 6-12 bulan di wilayah kerja Puskesmas Simpang Baru Kota Pekanbaru tahun 2016 dan sampel penelitian ini adalah sebagian ibu yang mempunyai bayi $6-12$ bulan di wilayah kerja Puskesmas Simpang Baru Kota Pekanbaru tahun 2016 sebanyak 151 orang yang memenuhi kriteria sampel. Pengambilan sampel dilakukan dengan tehnik systematic random sampling.Dengan prosedur ini disusun 
pula kerangka sampel yang terdiri atas unit penelitian dengan nomor urut tertentu. Misalnya 0001 sampai dengan 627. Dengan data ini dapat dihitung sampling faction yaitu $(627: 151=4,1)$ dibulatkan menjadi 4, kemudian menggunakan buku random hanya ditemukan 1 nomor, misalnya ditemukan nomor 010. Nomor unit sampel berikutnya ditambahkan 4 menjadi 014, lalu selanjutnya 018...lalu melewati 627, sehingga didapatkan ukuran sampel sebanyak 151. Pengumpulan data dilakukan dengan wawancara menggunakan kuesioner, pengukuran langsung, dan observasi. Data karakteristik subjek meliputi pendidikan ibu, pekerjaan ibu, tanggal lahir bayi, riwayat penyakit bayi, berat badan bayi baru lahir, ASI eksklusif, pengetahuan ibu di kumpulkan menggunakan kuesioner, konsumsi makanan bayi dilakukan dengan cara recall 24 jam, dan lingkungan pengasuhan dilakukan dengan observasi menggunakan home inventory, sedangkan untuk berat badan bayi diukur langsung menggunakan timbangan bayi serta untuk pengukuran perkembangan menggunakan Denver dilakukan dengan observasi. Pengolahan data dilakukan dalam tahap-tahap editing, coding, processing, cleaning dan tabulating. Analisis data dilakukan secara univariat, bivariat dengan uji chi square dan analisis multivariat dengan multinomial logistic regressio

\section{HASIL DAN PEMBAHASAN}

1. HASIL

Tabel 1 Analisa Univariat variabel dependan dan independen

\begin{tabular}{lcc} 
& Variabel & \multicolumn{2}{c}{ Jumlah } \\
\cline { 2 - 3 } & $(\mathrm{n}=151)$ & $(100 \%)$ \\
\hline Tumbuh kembang & & \\
Gangguan pertumbuhan & 23 & 15 \\
Gangguan perkembangan & 41 & 27 \\
Gangguan tumbuh kembang & 57 & 38 \\
ASI Eksklusif & & \\
$\quad$ Tidak & 67 & 44,4 \\
Ya & 84 & 55,6 \\
Pengetahuan & & \\
Kurang & 66 & 43.7 \\
Baik & 85 & 56.3 \\
Lingkungan Pengasuhan & & \\
Kurang & 32 & 21.2 \\
Cukup & 59 & 39.1 \\
Baik & 60 & 39.7 \\
Konsumsi Makanan & & \\
Tidak Cukup & 63 & 41.7 \\
Cukup & 88 & 58,3 \\
Riwayat Penyakit & & \\
Ada & 59 & 39.1 \\
Tidak Ada & 92 & 60.9 \\
Berat Badan Lahir & & \\
Tidak Normal & 51 & 33,8 \\
Normal & 100 & 66,2
\end{tabular}




\begin{tabular}{lcc} 
Pendidikan Ibu & & \\
SD & 21 & 13,9 \\
SMP & 24 & 15,9 \\
SMA & 68 & 45,0 \\
PT & 38 & 25,2 \\
Pekerjaan Ibu & & \\
Swasta & 20 & 13,2 \\
Berdagang & 15 & 9,9 \\
PNS & 24 & 15,9 \\
IRT & 92 & 60,9 \\
\hline
\end{tabular}

Sumber: Data Primer Agustus 2016

Tabel 2. Analisa Bivariat Hubungan beberapa variabel independen terhadap tumbuh kembang bayi

\begin{tabular}{|c|c|c|c|c|c|c|c|c|c|c|c|}
\hline \multirow{3}{*}{$\begin{array}{l}\text { Variabel } \\
\text { Independen } \\
\text { dan Kategori }\end{array}$} & \multicolumn{8}{|c|}{ Tumbuh Kembang Bayi } & \multicolumn{2}{|c|}{ Jumlah } & \multirow{3}{*}{ Pvalue } \\
\hline & \multicolumn{2}{|c|}{$\begin{array}{c}\text { Gangguan } \\
\text { Tumbuh } \\
\text { Kembang }\end{array}$} & \multicolumn{2}{|c|}{$\begin{array}{c}\text { Gangguan } \\
\text { Pertumbuhan }\end{array}$} & \multicolumn{2}{|c|}{$\begin{array}{l}\text { Gangguan } \\
\text { Perkemban } \\
\text { gan }\end{array}$} & \multicolumn{2}{|c|}{ Normal } & \multirow[t]{2}{*}{$\mathrm{n}$} & \multirow[t]{2}{*}{$(\%)$} & \\
\hline & $\mathrm{n}$ & $(\%)$ & $\mathrm{N}$ & $(\%)$ & $\mathrm{N}$ & $(\%)$ & $\mathrm{N}$ & $(\%)$ & & & \\
\hline \multicolumn{12}{|l|}{ ASI Eksklusif } \\
\hline Tidak & 28 & $(41,8)$ & 12 & $(17,9)$ & 13 & $(19,4)$ & 14 & $(20,9)$ & 67 & (100) & $<0,001$ \\
\hline $\mathrm{Ya}$ & 13 & $(15,5)$ & 11 & $(13,1)$ & 17 & $(20,2)$ & 43 & $(51,2)$ & 84 & (100) & \\
\hline \multicolumn{12}{|l|}{ Pengetahuan } \\
\hline Kurang & 25 & $(37,9)$ & 13 & $(19,7)$ & 12 & $(18,2)$ & 16 & $(24,2)$ & 66 & $(100)$ & 0,006 \\
\hline Baik & 16 & $(18,8)$ & 10 & $(11,8)$ & 18 & $(21,2)$ & 41 & $(48,2)$ & 85 & $(100)$ & \\
\hline \multicolumn{12}{|l|}{ Lingkungan } \\
\hline \multicolumn{12}{|l|}{ Pengasuhan } \\
\hline Kurang & 15 & $(46,9)$ & 2 & $(6,3)$ & 8 & $(25,0)$ & 7 & $(21,9)$ & 32 & $(100)$ & $<0,001$ \\
\hline Cukup & 17 & $(28,8)$ & 14 & $(23,7)$ & 15 & $(25,4)$ & 13 & $(22,0)$ & 59 & $(100)$ & \\
\hline Baik & 9 & $(15,0)$ & 7 & $(11,7)$ & 7 & $(11,7)$ & 37 & $(61,7)$ & 60 & $(100)$ & \\
\hline \multicolumn{12}{|l|}{ Konsumsi } \\
\hline \multicolumn{12}{|l|}{ Makanan } \\
\hline Tidak Cukup & 19 & $(30,2)$ & 15 & $(22,2)$ & 15 & $(23,8)$ & 15 & $(23,8)$ & 63 & (100) & 0,017 \\
\hline Cukup & 22 & $(25.0)$ & 9 & $(10,2)$ & 15 & $(17,0)$ & 42 & $(47,7)$ & 88 & (100) & \\
\hline \multicolumn{12}{|l|}{ Riwayat } \\
\hline \multicolumn{12}{|l|}{ Penyakit } \\
\hline Ada & 14 & $(23,7)$ & 11 & $(18,6)$ & 13 & $(22,0)$ & 21 & $(35,6)$ & 59 & (100) & 0,681 \\
\hline Tidak Ada & 27 & $(29.3)$ & 12 & $(13,0)$ & 17 & $(18,5)$ & 36 & $(39,1)$ & 92 & (100) & \\
\hline \multicolumn{12}{|l|}{ Berat Badan } \\
\hline \multicolumn{12}{|l|}{ Lahir } \\
\hline Tidak & 17 & & 8 & $(15,7)$ & 11 & $(21,6)$ & 15 & $(29,4)$ & 51 & (100) & 0,453 \\
\hline Normal & & $(33,3)$ & & & & & & & & & \\
\hline Normal & 24 & & 15 & $(15,0)$ & 19 & $(19,0)$ & 42 & $(42,0)$ & 100 & (100) & \\
\hline & & $(24,0)$ & & & & & & & & & \\
\hline \multicolumn{12}{|l|}{ Pendidikan Ibu } \\
\hline Rendah & 14 & $(31,1)$ & 8 & $(17,8)$ & 6 & $(13,3)$ & 17 & $(37,8)$ & 45 & $(100)$ & 0,568 \\
\hline Tinggi & 27 & $(25,5)$ & 15 & $(14,2)$ & 24 & $(22,6)$ & 40 & $(37,7)$ & 106 & (100) & \\
\hline \multicolumn{12}{|l|}{ Pekerjaan Ibu } \\
\hline Bekerja & 27 & $(45,8)$ & 8 & $(13,6)$ & 10 & $(16,9)$ & 14 & $(23,7)$ & 58 & $(100)$ & $<0,001$ \\
\hline
\end{tabular}


$\begin{array}{lllllllllll}\text { Tidak } & 14 & (15,2) & 15 & (16,3) & 20 & (21,7) & 43 & (46,7) & 92 & (100)\end{array}$ Bekerja

Sumber: Data Primer Agustus 2016

Tabel 3 Analisa Multivariat

\begin{tabular}{|c|c|c|c|c|c|}
\hline \multirow{2}{*}{ No } & \multirow[t]{2}{*}{ Variabel } & \multirow[t]{2}{*}{ P value } & \multirow[t]{2}{*}{ POR } & \multicolumn{2}{|c|}{$(95 \%$ CI $)$} \\
\hline & & & & Lower & Upper \\
\hline \multirow{3}{*}{1.} & ASI eksklusif & 0,053 & 3,120 & 0,988 & 9.855 \\
\hline & & 0,274 & 1.807 & 0.626 & 5,217 \\
\hline & & 0,016 & 3,683 & 1,269 & 10,686 \\
\hline \multirow[t]{3}{*}{2.} & Pengetahuan ibu & 0,030 & 3,344 & 1,124 & 9,948 \\
\hline & & 0,363 & 1,591 & 0,585 & 4,331 \\
\hline & & 0,004 & 4,588 & 1,639 & 12,848 \\
\hline \multirow[t]{3}{*}{3.} & Lingkungan pengasuhan & 0,441 & 1,357 & 0,624 & 4,982 \\
\hline & & 0,005 & 2,586 & 1,329 & 5,034 \\
\hline & & 0,003 & 2,917 & 1,438 & 5,918 \\
\hline \multirow[t]{3}{*}{4.} & Konsumsi makanan & 0,027 & 3,418 & 1,152 & 10,140 \\
\hline & & 0,157 & 2,045 & 0,760 & 5,499 \\
\hline & & 0,591 & 1,330 & 0,470 & 3,760 \\
\hline \multirow[t]{3}{*}{5.} & Pekerjaan ibu & 0,509 & 1,498 & 0,451 & 4,982 \\
\hline & & 0,418 & 1,583 & 0,521 & 4,810 \\
\hline & & 0,002 & 5,406 & 1,836 & 15,914 \\
\hline
\end{tabular}

Model fitting information : $<0,001$

Nagelkerke R Square: 0,376

\section{PEMBAHASAN}

Pada penelitian ini ditemukan bahwa bayi yang tidak diberikan ASI eksklusif lebih berisiko 3,1 kali mengalami gangguan pertumbuhan dari yang normal (POR: 3,1; CI95\% 0,988$9,855), 217)$, bayi yang tidak diberikan ASI eksklusif lebih berisiko 1,8 kali mengalami gangguan perkembangan dari yang normal (POR: 1,8; CI95\% 0,626-5), dan bayi yang tidak diberikan ASI eksklusif lebih berisiko 3,6 kali mengalami gangguan tumbuh kembang dari yang normal (POR: 3,6; CI95\% 1,269-10,686). Menurut Sulistyoningsih (2011). Beberapa penelitian menunjukkan ada hubungan antara bayi yang mendapat ASI eksklusif dengan tumbuh kembang bayi. Hasil yang dilakukan oleh Andria, et al (2013) menunjukkan bahwa hasil pengukuran perkembangan $p$ value $=0,048$, dan hasil pengukuran pertumbuhan $p$ value $=0,043$. Sehingga dapat disimpulkan bahwa terdapat perbedaan antara pemberian ASI eksklusif dan susu formula terhadap tumbuh kembang bayi usia 612 bulan Kumboyono et al (2013). Menunjukkan bahwa hasil pengukuran perkembangan $p$ value $=0,012$, dan hasil pengukuran pertumbuhan $p$ value $=0,03$. Sehingga dapat disimpulkan bahwa terdapat perbedaan antara pemberian ASI eksklusif dan susu formula terhadap tumbuh kembang bayi.

ASI merupakan makanan dibutuhkan untuk kesehatan bayi dan mendukung pertumbuhan dan perkembangan bayi secara optimal. Bayi yang mendapatkan ASI eksklusif akan memperoleh semua kelebihan ASI serta terpenuhinya kebutuhan gizinya secara maksimal sehingga bayi lebih 
sehat, lebih tahan terhadap infeksi, tidak mudah terkena alergi, dan lebih jarang sakit karena ASI mengandung antibodi. Dengan demikian jika bayi yang mendapatkan ASI sacara eksklusif akan mengalami pertumbuhan yang optimal, hal ini dapat dilihat dari penambahan berat badan, panjang badan, atau lingkar kepala. ASI juga merpkanan makanan untuk perkembangan otak anak.ASI mengandung kolesterol tinggi yang diperlukan untuk mielinisasi. Demikian juga kadar AA dan DHA juga tinggi pada ASI. Anak yang mendapatkan ASI mempunyai kecerdasan yang lebih baik dari pada yang tidak mendapatkan ASI (Soetjiningsih, 2014).

Pekerjaan ibu juga berhubungan sebab akibat dengan tumbuh kembang bayi. Bayi dari ibu yang bekerja lebih berisiko 1,4 kali mengalami gangguan pertumbuhan dari yang normal, bayi dari ibu yang bekerja lebih berisiko 1,5 kali mengalami gangguan perkembangan dari yang normal, dan bayi dari ibu yang bekerja lebih berisiko 5,4 kali mengalami gangguan tumbuh kembang dari yang normal. Menurut Markum dalam buku Nursalam (2005) dijelaskan bekerja umumnya merupakan kegiatan yang menyita waktu untuk menunjang kehidupan dalam keluarga dimana ibu rumah tangga akan memiliki waktu yang lebih maksimal sehingga dapat mengetahui segala aktifitas anaknya. Orang tua yang tidak bekerja dapat memberikan stimulasi dengan baik karena ibu mempunyai banyak waktu untuk merawat bayinya termasuk memberikan stimulasi dengan frekuensi yang lebih intensif.

Ibu yang tidak bekerja mempunyai banyak waktu memberikan
ASI secara eksklusif sehingga ibu dapat memantau pertumbuhan bayi dengan membawa bayi ke posyandu sehingga ibu dapat mengetahui kenaikan berat badan dan panjang badan, sedangkan ibu yang bekerja hanya sedikit mempunyai waktu untuk bayinya dan tidak sempat membawa bayinya ke posyandu sehingga ibu tidak dapat memantau pertumbuhan bayi.

Pengetahuan ibu juga berhubungan sebab dengan tumbuh kembang bayi. Bayi dari ibu yang berpengetahuan kurang lebih berisiko 3,3 kali mengalami gangguan pertumbuhan dari yang normal, bayi dari ibu yang berpengetahuan kurang lebih berisiko 1,5 kali mengalami gangguan perkembangan dari yang normal, dan bayi yang berpengetahuan kurang lebih berisiko 4,5 kali mengalami gangguan tumbuh kembang dari yang normal. Beberapa penelitian menunjukkan bahwa pengetahuan ibu berhubungan dengan tumbuh kembang bayi Hasil yang dilakukan oleh Laiya, et al (2014) sebanyak 21 responden 45,6 persen berpengetahuan cukup dengan perkembangan motorik kasarnya baik sesuai tahap perkembangan. Hasil ini menunjukkan nilai p-value sebesar $0,000<0,005$ artinya ada hubungan antara pengetahuan ibu dengan perkembangan anak. Hasil penelitian yang dilakukan oleh Pratiwi (2014) uji statistik dengan menggunakan Spearman's Rho didapatkan nilai $\mathrm{p}=0.000(<0.05)$ untuk pertumbuhan dan $\mathrm{p}=0.000(<$ 0.05) untuk perkembangan. Hasil tersebut menunjukan bahwa ibu yang memiliki tingkat pengetahuan yang tinggi pertumbuhan dan perkembangan anaknya lebih baik dibandingkan dengan ibu yang 
memiliki tingkat pengetahuan cukup dan rendah.

Pengetahuan atau kognitif adalah hal yang sangat penting dalam membentuk tindakan seseorang, salah satunya kurang memadai pengetahuan ibu mengenai ASI yang menjadi penyebab atau masalah tumbuh kembang bayi.Pengetahuan ibu yang kurang akan berpengaruh terhadap tumbuh kembang bayi dibandingkan dengan ibu yang berpengetahuan baik (Roesli, 2008).

$$
\text { Lingkungan pengasuhan }
$$

berhubungan sebab akibat dengan tumbuh kembang bayi. bayi dengan lingkungan pengasuhan yang kurang lebih berisiko 1,3 kali mengalami gangguan pertumbuhan dari yang normal, bayi dengan lingkungan pengasuhan yang kurang lebih berisiko 2,5 kali mengalami gangguan perkembangan dari yang normal, dan bayi lingkungan pengasuhan yang kurang lebih berisiko 2,9kali mengalami gangguan tumbuh kembang dari yang normal. Tumbuh kembang anak dipengaruhi oleh lingkungan, yang bersifat sementara maupun permanen serta dapat mempengaruhi kecepatan kualitastumbuh kembang anak.Lingkungan disekitar anak merupakan potensi risiko terhadap tumbuh kembang anak (Soetjiningsih, 2014). Lingkungan pengasuhan yang baik akan mempengaruhi tumbuh kembang bayi. Bayi dengan lingkungan pengasuhan yang baik akan mengalami tumbuh kembang yang normal bila dibandingkan dengan bayi yang lingkungan pengasuhannya kurang akan mengalami gangguan tumbuh kembang bayi.

Konsumsi makanan

berhubungan sebab akibat dengan tumbuh kembang bayi. Bayi dengan kebutuhan protein tidak cukup lebih berisiko 3,4 kalimengalami gangguan pertumbuhan dari yang normal, bayi dengan kebutuhan protein tidak cukup lebih berisiko 2,0 kalimengalami gangguan perkembangan dari yang normal, dan bayi dengan kebutuhan protein tidak cukup lebih berisiko 1,3kali mengalami gangguan tumbuh kembang dari yang normal. Pemberian makanan pendamping selain ASI (MPASI) mulai dilakukan setelah bayi berusia 6 bulan.MPASI dibutuhkan untuk memenuhi kebutuhan pangan bayi yang semakin meningkat sesuai dengan umur. Pemberian MPASI baik jenis, porsi, dan frekuensi tergantung dari usia dan kemampuan bayi. Jika pemberian MPASI tidak sesuai dengan kemampuan bayi maka bayi akan mengalami gangguan pencernaan seperti diare sehingga bayi mengalami penurunan berat badan dan mengganggu pertumbuhan (Sulistyoningsih, 2011).

Makanan yang kurang baik secara kualitas maupun kuantitas akan menyebabkan gizi kurang. Keadaan gizi kurang dapat menyebabkan gangguan pertumbuhan dan perkembangan, khusus pada perkembangan dapat mengakibatkan perubahan struktur dan fungsi otak.Otak manusia mengalami perubahan struktural dan fungsional yang luar biasa antara minggu ke-24 sampai minggu ke-42 setelah konsepsi. Perkembangan ini berlanjut setelah lahir hingga usia 2 atau 3 tahun, periode tercepat usia 6 bulan pertama kehidupan. Dengan demikian pertumbuhan sel otak berlangsung sampai usia 3 tahun (Soetjiningsih, 2014).Penelitian ini menunjukkan tidak ditemukan adanya hubungan signifikan antara riwayat penyakit dengan tumbuh 
kembang bayi. Hasil penelitian ini berbanding terbalik dengan hasil penelitian Astuti (2010) Berdasarkan uji statistik di peroleh nilai $\mathrm{p}$ sebesar $0,001(\mathrm{p}<0,05)$ yang berarti bahwa ada hubungan antara riwayat penyakit ISPA dan Diare dengan tumbuh kembang, dengan nilai nilai Odd Ratio (OR) yang diperoleh sebanyak 18,947 yang menunjukkan anak yang memiliki riwayat penyakit ISPA dan Diare berpeluang 18,947 kali mengalami tumbuh kembang yang tidak sesuai dengan usianya di bandingkan anak yang tidak memiliki riwayat penyakit ISPA dan Diare. Hal ini tidak berhubungan mungkin terjadi recall bias karena responden menjawab hanya berdasarkan ingatannya. Hasil penelitian menemukan bahwa sebagian besar bayi tidak ada riwayat penyakit diare.

Pada variabel pendidikan juga tidak berhubungan signifikan dengan tumbuh kembang bayi. Hasil penelitian ini tidak sesuai dengan penelitian terdahulu yakni hasil penelitian Harahap (2011), menyatakan bahwa anak dari ibu berpendidikan rendah (SMP kebawah) berpeluang untuk mengalami gangguan perkembangan sebesar 1,8 kali dibandingkan anak dari ibu yang berpendidikan tinggi (SMA keatas). Hal penelitian ini tidak berhubungan dikarenakan terjadi bias informasi karena pendidikan tidak selalu menjadi alat ukur pengetahuan seseorang.dalam penelitian ini responden dominan pendidikan SMA dan sarjana dengan kategori pendidikan tinggi. Pendidikan tinggi tidak menjamin seseorang mengetahui semua hal terutama tentang tumbuh kembang bayi, dan pendidikan rendah berkemungkinan tahu dalam sesuatu hal salah satunya tentang tumbuh kembang bayi. Selain variabel pendidikan ada variabel yang tidak berhubungan yaitu berat badan lahir dengan tumbuh kembang bayi. Hal ini kemungkinan terjadi karena hanya sedikit bayi yang lahir dengan berat badan tidak normal dan hal ini juga dipengaruhi oleh usia kehamilan cukup bulan atau tidak cukup bulan saat melahirkan. Berat badan lahir tidak normal berkaitan dengan pertumbuhan sedangkan usia kehamilan saat lahir berkaitan dengan perkembangan.

\section{SIMPULAN}

Proporsi bayi yang mengalami gangguan tumbuh kembang sebanyak 41 orang $(27 \%)$. ASI eksklusif merupakan variable yang paling dominan mempengaruhi tumbuh kembang bayi. Bayi yang tidak mendapatkan ASI eksklusif lebih berisiko 1,8 kali mengalami gangguan perkembangan dari yang normal, bayi yang tidak mendapatkan ASI eksklusif lebih berisiko 3,1 kali mengalami gangguan pertumbuhan dari yang normal dan bayi yang tidak mendapatkan ASI eksklusif lebih berisiko 3,6 kali mengalami gangguan tumbuh kembang dari yang normal. variabel confounding dalam penelitian ini yaitu variabel pengetahuan ibu, pekerjaan ibu, lingkungan pengasuhan, konsumsi makanan. Variabel independen yang tidak memiliki hubungan signifikan secara statistik dengan tumbuh kembang bayi adalah riwayat penyakit, berat badan lahir, pendidikan ibu. Kepada instansi terkait yang bertanggung jawab sebagai unit pelaksana teknis pelayanan kesehatan masyarakat untuk memberikan penyuluhan dan melaksanakan atau menjalankan program pemerintah dalam meningkatkan pemberian ASI 
secara eksklusif serta membentuk kelompok khusus ibu yang memiliki bayi guna memberikan informasi

\section{DAFTAR PUSTAKA}

Achadi. Endang L. 2014. PeriodeKritis 1000 Hari Pertama Kehidupan dan Dampak Jangka Panjang Terhadap Kesehatan dan Fungsinya. Yogyakarta: Departemen Gizi Kesmas FKM UI. (di akses tanggal 09 Januari 2016).

Andria, dkk. 2013. Perbedaan Tumbuh Kembang Bayi Usia 6-12Bulan yang Menggunakan ASI Eksklusif dengan yang Menggunakan Susu Formula di Desa Sungai Sirih Kecamatan Singingi Kabupaten Kuantan Singingi Tahun 2013. Penelitian Dosen: Universitas Abdurrab.

Astuti, Rina. 2010. Hubungan antara riwayat ispa dan diare dengan tumbuh Kembang anak usia 1-5 tahun di posyandu Desa cetankabupatenklaten. (di akses tanggal 10 Januari 2016).

Dinas Kesehatan Riau. 2013. Profil Kesehatan Provinsi Riau.(di akses tanggal 09 Januari 2016).

Harahap, H. 2011. Risk Factors Associated With Mental Development of Indonesian Children Under - Five Years Old, ACN, (2015). 12 th Asian Congress of Nutrision, Mey 14 (thu) - 18 (mon,2015), Federation of Asian Nutrition Societien (FANS).

Kumboyono, dkk. 2013. Perbedaan Antara Pemberian ASI Eksklusif dan Susu Formula Terhadap Tumbuh kembang bayi usia 0-6 bulan di Wilayah Kerja Puskesmas tentang pemantauan tumbuh kembang bayi.

Dinoyo Kota Malang. .(di akses tanggal 15 Januari 2016).

Laiya, dkk. 2014. Hubungan Pengetahuan Ibu tentang Tumbuh Kembang Anak dengan Perkembangan Motorik Kasar Anak Usia 3-5 Tahun di Desa Bube Baru Kec.Suwawa Kab. Bone Bolango. Jurusan Ilmu Keperawatan FIKK UNG. (diakses tanggal 15 Januari 2016).

Muslihatun, Nur, Wafi. 2011. Asuhan Neonatus Bayi dan Balita. Yogyakarta: Fitramaya.

Nursalam, dkk. 2005. Asuhan Keperawatan Bayi dan Anak. Jakarta: Salemba medika.

Pratiwi, Wahyu Alfianti. 2014. Hubungan Pengetahuan, Sikap dan Perilaku Ibu tentang ASI Eksklusif terhadap Tumbuh Kembang Anak usia 6 - 24 Bulan di Kabupaten Merauke. Sekripsi, Program Studi Ilmu Keperawatan Fakultas Kedokteran dan Ilmu Kesehatan Universitas Muhammadiyah Yogyakarta. (diakses tanggal 15 Januari 2016).

Riset Kesehatan Dasar. 2013. Jumlah Status Gizi Balita Di Indonesia.

Roesli, Utami. 2008. Mengenal ASI Esklusif. Jakarta; Trubus Agriwidya.

Sarlis, Nelfi.2015. Stimulasi Dini Terhadap Perkembangan Bayi Usia Enam Bulan di Wilayah kerja Puskesmas Garuda Pekanbaru Tahun 2015. Tesis: STikes Hangtuah.

Soetjiningsih. 2014. Tumbuh Kembang Anak. Jakarta. EGC. 
Sulistyoningsih, Hariyani. 2011. Gizi untuk Kesehatan Ibu dan Bayi. Yogyakarta: Graha Ilmu.
Yuniarti, Sri. 2015. Asuhan Tumbuh Kembang Neonatus, Bayi, Balita, dan Anak Prasekolah. Bandung: Rafika Aditama. 